\title{
Efek Amelioratif VCO terhadap Heterofil Ayam Broiler yang divaksinasi AI
}

\section{Ameliorative Effect of VCO on Heterophile of Broiler Chicken Vaccinated AI}

\author{
Enny Yusuf Wachidah Yuniwarti \\ Departemen Biologi, Fakultas Sains dan Matematika, Universitas Diponegoro \\ Jl. Prof. Soedarto, SH, Tembalang, Semarang \\ Email : enny_yusuf@yahoo.co.id
}

Diterima 13 Juni 2017 / Disetujui 28 Agustus 2017

\begin{abstract}
ABSTRAK
Penelitian ini bertujuan untuk meningkatkan jumlah heterofil sebagai efek baik VCO terhadap pencegahan penyakit avian influenza (AI) pada ayam pedaging melalui peningkatan daya tahan tubuh. Penelitian ini menggunakan 40 ekor ayam broiler umur satu hari. Desain penelitian yang digunakan adalah Rancangan Acak Lengkap dengan kelompok pertama, kedua, ketiga, keempat, kelima merupakan kelompok ayam yang divaksin AI dengan penambahan VCO masing-masing 0,6,12,15 dan $18 \mathrm{~mL} / \mathrm{kg}$ pakan, kelompok enm, tujuh, delapan, sembilan dan sepuluh merupakan ayam yang tidak divaksin AI dan penambahan VCO masingmasing 0,6,12, 15 dan $18 \mathrm{~mL} / \mathrm{kg}$ pakan. Ayam broiler dikelompokkan dalam 10 kelompok perlakuan dan dilakukan pengulangan dalam 4 unit percobaan. Pakan dan minum diberikan ad libitum selama 4 minggu. Hasil penelitian menunjukkan bahwa jumlah heterofil tidak dipengaruhi oleh vaksinasi AI maupun pemberian VCO, sehingga dapat disimpulkan jika peningkatan derajad kesehatan ayam setelah pemberian VCO dan vaksinasi AI tidak melalui peningkatan jumlah heterofil.
\end{abstract}

Kata kunci: avian influenza, ayam pedaging, VCO, heterofil

\section{ABSTRACT}

This research aimed to increase number of heterophile as an effect ameliorative VCO to AI disease prevention through increase chicken immunity. This research used 40 one-day-old broiler chickens. The method applied was Completely Randomized Design in which the first, second, third, fourth, fifth groups was combine of chicken vaccination AI with VCO 0,6,12,15, $18 \mathrm{~mL} / \mathrm{kg}$ feed, and the sixth, seventh, eight, ninth, tenth groups was combine of chicken without vaccination AI with VCO 0,6,12,15, $18 \mathrm{~mL} / \mathrm{kg}$ feed. Day Old Chick (DOC) were divided into ten treatment groups and repeated four times. Feed and water were given ad libitum for four weeks. The result showed that the number of heterophil not influenced by the AI vaccination and feeding VCO.

Keywords: Avian influenza, chicken, VCO, heterophile

\section{PENDAHULUAN}

Profil darah merupakan indeks status kesehatan yang penting bagi hewan maupun manusia. Profil heterofil ayam dapat digunakan untuk mengetahui apakah ayam tersebut shat atau sakit (Khan dan Zafar, 2005). Heterofil merupakan leukosit polimorfonuklear utama pada ayam yang berfungsi memodulasi respon imun, produksi oksigen intermediate, dan pelepasan enzim proteolitik (Swaggerty et al., 2004). Heterofil pada ayam setara dengan neutrofil pada mammalia, sehingga berperan sebagai sel yang mengawali mekanisme pemusnahan mikrobia. Produksi sitokin dari heterofil menunjukkan bahwa heterofil mampu berperan penting dalam mengatur pro dan anti inflamasi. Heterofil juga berperan sebagai imunoregulator karena heterofil merupakan sel yang kontak dan berinteraksi dengan agen inflamasi. Kemampuan heterofil dalam mensintesis dan melepaskan serangkaian sitokin memberikan bukti bahwa heterofil mampu berperan sebagai imunoregulator (Kogut et al., 2005). 
Sistem kekebalan tubuh ayam dapat distimulasi oleh pemberian vaksinasi, khususnya vaksinasi AI yang diharapkan mampu memberikan proteksi terhadap virus Avian influenza.

Rangsangan antigen yang sudah diproses, akan menyebabkan sel-sel imun berproliferasi dan berdiferensiasi, sehingga menjadi sel yang memiliki kompetensi imunologik dan mampu bereaksi dengan antigen. Pada respon primer atau kontak pertama, antigen dapat dimusnahkan sehingga sel-sel sistem imun kemudian mengadakan involusi (Kaspers et al., 2008). Antigen akan mengikat antibodi secara spesifik, ikatan antigen-antibodi akan menginaktivasi virus melalui blocking kemampuan virus untuk mengikat reseptor sel inang.

Ikatan antibodi juga memediasi patogen untuk dihancurkan, terutama melalui sel-sel fagositik dari sistem imun innate (Albert et al., 2002). Peningkatan daya tahan tubuh merupakan alternatif pencegahan penyakit avian influenza (AI) pada ayam pedaging karena virus $\mathrm{H} 5 \mathrm{~N} 1$ mempunyai sifat mudah mengalami mutasi (Peiris et al, 2007) dan cenderung dapat menimbulkan penyakit yang terbatas pada suatu kawasan (Suarez and Cherry, 2000). Sifat virus AI tersebut menyebabkan vaksinasi terhadap AI yang diberikan pada ayam tidak selalu dapat melindungi ayam dari serangan virus AI (Perkin and Swayne, 2003).

Virgin Coconut Oil (VCO) merupakan food supplement yang dapat diproduksi di Indonesia, mengandung asam laurat, asam miristat, asam palmitat, asam kaprilat, asam kaprat, asam oleat, asam stearat dan asam kaproat. Kandungan terbesar adalah asam laurat yang terdapat lebih dari $50 \%$. Beberapa penelitian menunjukkan bahwa pemberian VCO sebesar $10 \mathrm{ml}$ per $\mathrm{kg}$ pakan mampu meningkatkan heterofil ayam broiler yang divaksin AI (Yuniwarti et al., 2012), sedangkan asam lemak dalam VCO juga berpotensi sebagai antivirus (Bartolotta et al., 2001).

Penelitian ini bertujuan untuk mengetahui apakah virgin coconut oil mampu memberikan efek amelioratif yaitu pengaruh yang baik, melalui peningkatan jumlah heterofil pada ayam pedaging yang divaksinasi maupun tidak divaksinasi AI.

\section{METODE PENELITIAN}

Penelitian ini menggunakan 40 ekor ayam broiler umur satu hari (DOC). Kandang yang digunakan adalah kandang kolektif untuk 10 ekor ayam sampai ayam berumur 2 minggu, kemudian dipindah ke kandang individu sampai umur 5 minggu. Kandang dilengkapi dengan tempat pakan dan tempat air minum. Penempatan ayam pada masing-masing kandang dilakukan secara acak. Pakan kontrol yang digunakan adalah pelet BR1 buatan pabrik, sedangkan pakan perlakuan merupakan pakan kontrol yang dicampur dengan VCO secara manual sesuai dengan perlakuan yang diberikan yaitu masing-masing $6 \mathrm{ml}, 12 \mathrm{ml}, 15 \mathrm{ml}$ dan $18 \mathrm{ml}$ VCO per kg pakan. Virgn coconut oil yang digunakan didapatkan dari pabrik sehingga konsistensi kualitasnya terjamin. Pakan dan minum diberikan ad libitum, vaksinasi AI sub type H5N1 diberikan kepada kelompok ayam yang divaksinasi secara intramuscular sebesar $0,5 \mathrm{ml}$. Peubah yang diamati adalah jumlah heterofil ayam. Darah ayam dikoleksi pada akhir perlakuan, diambil dari vena sayap dan ditampung pada tabung $2 \mathrm{ml}$ untuk penentuan leukosit, selanjutnya dibuat preparat apus darah yang diamati dibawah mikroskop dan dihitung persentase heterofil nya menggunakan differential count. Persentase heterofil yang didapat selanjutnya dikalikan dengan jumlah leukosit, sehingga didapat jumlah heterofil.

Penelitian ini menggunakan Rancangan Acak Lengkap (RAL) dengan 10 perlakuan dan 4 ulangan. Ayam dikelompokkan dalam 10 kelompok perlakuan yaitu kelompok 1 merupakan kelompok ayam yang divaksin AI tanpa pemberian VCO, kelompok 2 merupakan kelompok ayam yang divaksin AI dengan pemberian VCO $6 \mathrm{ml}$ per kg pakan, kelompok 3 merupakan kelompok ayam yang divaksin AI dengan pemberian VCO $12 \mathrm{ml}$ per kg pakan, kelompok 4 merupakan merupakan kelompok ayam yang divaksin AI dengan pemberian VCO $15 \mathrm{ml}$ per kg pakan, kelmpok 5 merupakan kelompok ayam yang divaksin AI dengan pemberian VCO $18 \mathrm{ml}$ per $\mathrm{kg}$ pakan, kelompok 6 merupakan kelompok ayam yang tidak divaksin AI tanpa pemberian VCO, kelompok 7 merupakan kelompok ayam yang 
tidak divaksin AI dengan pemberian VCO $6 \mathrm{ml}$ per kg pakan, kelompok 8 merupakan kelompok ayam yang tidak divaksin AI dengan pemberian VCO 12 $\mathrm{ml}$ per $\mathrm{kg}$ pakan, kelompok 9 merupakan kelompok ayam yang tidak divaksin AI dengan pemberian VCO $15 \mathrm{ml}$ per kg pakan, kelompok 10 merupakan kelompok ayam yang tidak divaksin AI dengan pemberian VCO $18 \mathrm{ml}$ per kg pakan. Tiap perlakuan diulang dalam 4 unit percobaan. Perlakuan selama 4 minggu dan pada minggu ke 5 dilakukan koleksi sampel untuk pengambilan data. Data yang didapat selanjutnya dianalisis dengan ANOVA (Gomes and Gomes, 1984).

\section{HASIL DAN PEMBAHASAN}

Berdasarkan hasil analisis data menggunakan ANOVA dengan rancangan dasar acak lengkap, sepuluh perlakuan dengan empat ulangan, menunjukkan tidak ada beda nyata antar perlakuan terhadap jumlah heterofil ayam broiler, sehingga jumlah heterofil tersebut tidak dapat ditingkatkan jumlahnya, baik diberi vco maupun tidak diberi vco, juga divaksinasi AI maupun tidak divaksinasi AI, sebagaimana nampak pada gambar 1.

Vaksinasi terhadap AI akan menstimulasi sel B untuk menghasilkan antibodi sehingga akan meningkatkan aktivitas fagositosis makrofag karena antibodi ini berperan sebagai opsonin (Abbas et al., 2007). Vaksinasi akan menyebabkan adanya respon antibodi humoral dengan intensitas respon antibodi yang berbeda-beda pada tiap spesies aves. Respon antibodi humoral merupakan sumber utama perlindungan. Antibodi terhadap protein hemagglutinin (HA) merupakan antibodi yang paling penting karena dapat menetralkan virus dan mencegah virus memulai infeksi.Netralisasi meliputi pemblokiran ikatan virus ke sel inang dan dapat bekerja pada proses lain yang terlibat dalam masuknya virus. Antibodi terhadap protein neuraminidase (NA) memiliki beberapa efek perlindungan karena berperan untuk memperlambat penyebaran virus (Hunt, 2009). Vaksinasi AI pada ayam juga terbukti meningkatkan jumlah limfosit Th (Gioia et al., 2008), dan virus AI juga terbukti meningkatkan aktivasi limfosit ayam (Holt, 1990).

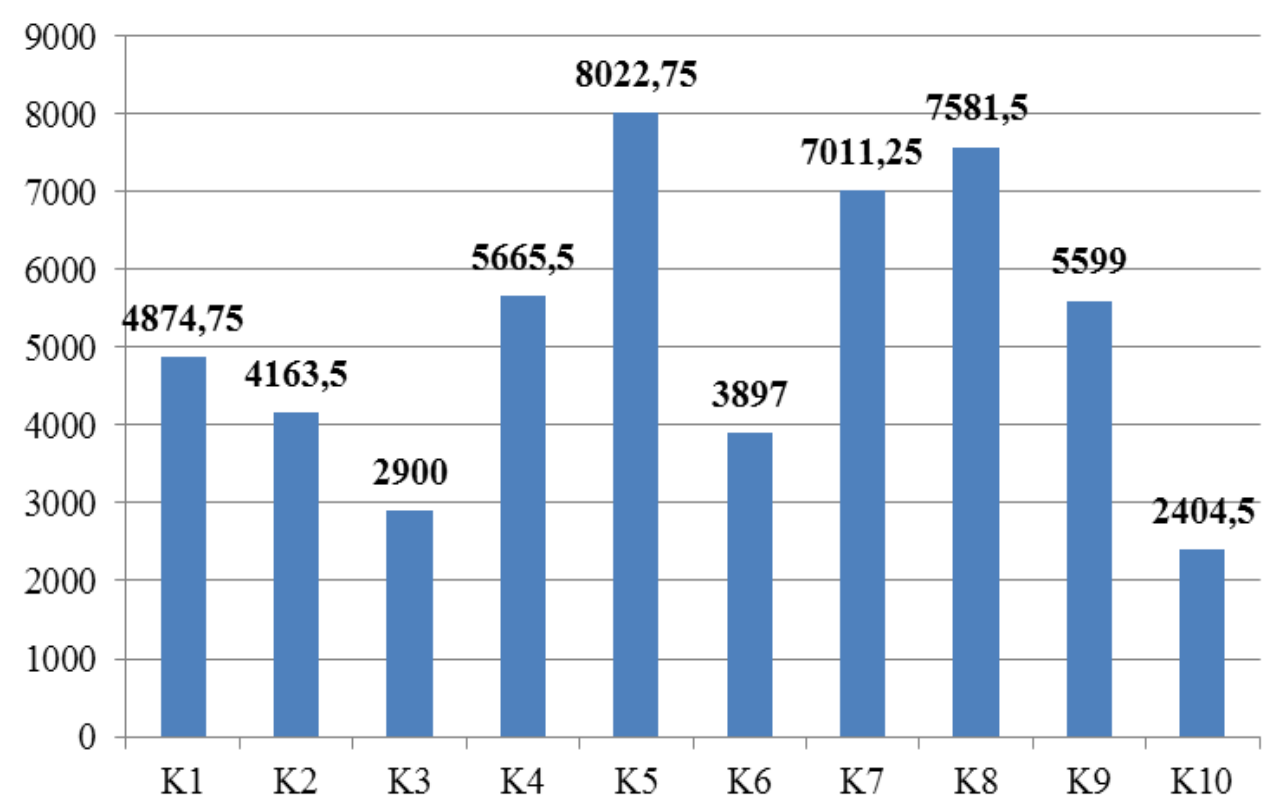

Gambar 1. Jumlah heterofil ayam broiler setelah pemberian berbagai dosis VCO dan vaksinasi AI

Perlakuan vaksinasi AI pada penelitian ini, tidak mampu meningkatkan jumlah heterofil ayam broiler karena diperkirakan terkait dengan fungsi heterofil dalam sistem kekebalan tubuh secara menyeluruh, karena vaksinasi dengan menggunakan virus avian influenza yang sudah tidak aktif dapat mengaktivasi antigen ( Holt, 1990) sehingga akan memicu respon imun bawaan 
melalui ekspresi berbagai reseptor yang terlibat dalam pathogenesis (Kogut et al., 2003).

Heterophil merupakan first line pertahanan seluler terhadap invasi mikroba patogen, komponen utama leukosit, bergranula, dan merespon inflamasi akut melalui aktifitas fagositosis serta mempunyai aktivitas antimikrobia berspektrum luas (Harmon, 1998). Heterophil akan dengan cepat dibawa ke lokasi infeksi dan terjadi proses fagositosis. Heterofil pada arteri akan berinteraksi dengan reseptor pada endothelial melalui dinding arteri mengikuti gradiend kemotaksis menuju ke tempat terjadinya sel yang mengalami inflamasi.

Faktor kemotaksis didapatkan dari campuran serum atau plasma dengan bakteri. Beta-defensin yang ditemukan pada granula heterofil merupakan kelompok peptida kationik, lysozym dan asam phosphatase. Enzim yang didapatkan di dalam granula heterofil adalah enzim hidrolisis glukoronidase, cathepsin dan asam glukosidase, hal tersebut menunjukkan bahwa heterofil mempunyai kemampuan fagositosis (Hea et al., 2005). Kemampuan heterofil melakukan proses diapedesis tersebut menyebabkan jumlah heterofil di darah pada ayam yang divaksinasi AI menjadi tidak berbeda nyata dengan ayam yang tidak divaksinasi AI.

Efek amelioratif VCO terhadap jumlah heterofil ternyata tidak terjadi karena jumlah heterofil tidak berbeda nyata pada semua perlakuan. Tambahan VCO dalam pakan diharapkan mampu memberikan tambahan energi yang dihasilkan oleh VCO, karenaVCO dapat menghasilkan tambahan energi metabolisme dengan cara melakukan resirkulasi ke dalam hepar melalui arteri hepatika (Enig, 2010). Tambahan energi dari VCO tidak digunakan untuk diferensiasi heterofil karena selain energi juga diperlukan beberapa sitokin untuk stimulasi diferensiasi heterofil.

\section{KESIMPULAN}

Pemberian VCO dalam pakan dan vaksinasi AI tidak mampu memberikan efek amelioratif terhadap sel heterofil ayam broiler.

\section{DAFTAR PUSTAKA}

Abbas A K, Lichtman AH, Pillai S, 2007. Cellular and Molecular Immunology, Saunders Elsevier.Philadelpia.

Alberts B, Johnson A, Lewis J, Raff M, Roberts K, Walter P, 2002. Mollecular Biology of the Cell, Garlandsciense.com. Bartolotta S, García CC, Candurra NA, Damonte EB, 2001. Effect of fatty acids on arenavirus replication: inhibition of virus production by lauric acid. Arch. Virol. 146(4):777-90.

Bain B J and FRC Path. 2005. Diagnosis from the blood smear. New England J. Medicine. 353:498-507.

Bartolotta S and CC García. 2001. Effect of fatty acids on Arenavirus replication: Inhibition of virus production by Lauric Acid. Arch Virol. 146(4):777-790.

Enig M, 2010. Action of Fatty Acid in Virgin Coconut Oil, www.Cocofat.Com

Gioia C, Castilletti C, Tempestilli M, Piacentini P, Bordi L, Chiappini R, Agrati C, Squarcione S, Ippolito G, Puro V,. Capobianchi MR, and Poccia F, 2008. Cross-subtype Immunity against Avian Influenza in Persons Recently Vaccinated for Influenza. Emerg Infect Dis. 14(1): 121-128.

Gomez KA and AA Gomez. 1995. Prosedur statistik untuk penelitian pertanian. Edisi kedua. Translated by: E Sjamsuddin and JS Baharsjah: Statistical procedure for agricultural research. UI Press, Jakarta, 698 pages.

Peiris MJS, MD de Jong and Y Guan. 2007. Avian influenza virus (H5N1): a threat to human health. Clinical Microbiology Reviews. 20(2):243-267.

Perkins LEL and DE Swayne. 2003. Varied pathogenicity of a hong kong origin $\mathrm{H} 5 \mathrm{~N} 1$ avian influenza virus in four passerine spesies and budgerigars. Veterinery Pathology. 40:14-24.

Harmon BG. 1998. Avian heterophiles in inflammation and disease resistance. Poult. Sci. 77:972-977. 
Hea H, VK Lowryb, PJ Ferroc and MH Koguta. 2005. CpG-oligodeoxynucleotide-stimulated chicken heterophile degranulation is serum cofactor and cell surface receptor dependent. Developmental and Comparative Immunology. 29:255-264.

Holt PS. 1990. Enhancement of chicken lymphocyte activation and lymphokine release by avian influenza virus. Developmental and Comparative Immunology. 14(4):447-455.

Kaspers B, Kothlow S, Butter C, 2008. Avian Antigen Presenting Cells: in Avian Immunology. Academic Press. Elsevier.

Khan T.A and F. Zafar. 2005. Haematological Study in Response to Varying Doses of Estrogen in Broiler Chicken. International Joutnal of Poultry Science. 4 (10). 748751.2005. ISSN 1682-8356.

Kogut MH, L Rothwell and P Kaiser. 2003. Differential regulation of cytokine gene expression by avian heterophiles during receptor-mediated phagocytosis of opsonized and nonopsonized Salmonella enteritidis. J. Interferon and Cy'fokine Res. 23:319-327.

Koguta Michael H., Muhammad Iqbalb, Haiqi Hea,Victoria Philbinb, Pete Kaiserb, Adrian Smith Expression and function of Toll-like Receptors in Chicken Heterophils. Developmental and Comparative Immunology 29 (2005) 791-807

Suarez DL and SS Cherry. 2000. Immunology of avian influenza virus: Review. J. Dev. and Comparative Immunology. 24(2-3):269-283.

Swaggerty Christina L., Pamela J. Ferro b,1, Igal Y. Pevzner c, Michael H. Kogut. 2005. Heterophils Are Associated With Resistance To Systemic Salmonella Enteritidis Infections In Genetically Distinct Chicken Lines. FEMS Immunology and Medical Microbiology 43 (2005) 149-154

Yuniwarti E. Y. W., W. Asmara, W. T. Artama and C. R. Tabbu. 2012. Virgin Coconut Oil Increases the Productivity of Broiler Chicken Post Avian Influenza Vaccination.
Animal Production 14(3):192-198, September 2012. 